\title{
HILDEBRANDO PÉREZ
} GRANDE: POEMAS

Presentación y selección de Javier Morales Mena

Doeta peruano miembro de la Generación poética de los años 60. Ha publicado el 1 poemario Aguardiente y otros cantares (1978) con el que obtuvo el prestigioso Premio de Poesía Casa de las Américas. También se le otorgó el Premio Internacional de Poesía Rafael Alberti (La Habana, Andalucía, 2013) por su infatigable vida dedicada a la poesía. En la década de los 70 fundó (y dirigió hasta su retiro), junto a Marco Martos, el taller de poesía de la Universidad Nacional Mayor de San Marcos, institución que en el 2015 lo distinguió como Profesor Emérito. Hildebrando Pérez Grande tiene una extensa e intensa vida poética que se traduce en diversos campos. Uno de los que cultiva hasta la fecha es el de docente (lo fue también en Francia por tres años). Desde esa honorable condición ha sabido provocar el interés y cultivar la sensibilidad poética en generaciones de jóvenes que el curso de la vida se ha encargado de modelar como narradores, poetas, críticos o intelectuales. Pero la inquietud lírica de este poeta-maestro no fue exclusivamente de gabinete, entre libros de cuero y butacas señoriales, lejos del polvo, el sudor y la sed. Él también conoció lo que fueron las protestas en las calles, los gases lacrimógenos y las persecuciones. Acaso por ello es que podemos encontrarlo, ahora, ¡a sus 77 heroicos ańos!, caminando tras las marchas de protesta contra la extensa lista de crímenes que el Estado no deja de acometer contra los ciudadanos.

Al margen de este magisterio poético de la vida, ejemplo demasiado escaso en nuestra ciudad letrada colmada de lobbistas y voyeurs, también como vigilante de la palabra poética de sus compañeros de generación, ha editado la poesía de Javier Heraud, Edgardo Tello y Juan Ojeda; y desde la condición de fundador de publicaciones, su aporte está 
plasmado en la dirección de dos revistas cuya importancia para el proceso de la poesía peruana de los años 60 es indudable: Piélago e Hipócrita Lector.

Se equivocan quienes piensan que el poeta está muerto. Léanse estas contadas líneas como un homenaje, como debieran ser todos, ¡en vida! Por la poesía que nos dio, por la que supo impartir en el aula y por la mano amiga y la palabra sincera que nunca dudó en ofrecerla a quien la buscara. Quienes actualmente lo gozan, están en la Universidad Antonio Ruiz de Montoya, en donde el poeta es docente. 


\section{Poemas}

\section{DE JULIO}

Yo soy el río que viaja por las calles...

Javier Heraud

Los viejos maestros dicen que nuestras vidas son los ríos interminables

Que pasando permanecen como un espejo encendido. Dones de la sabiduría

O el acaso, lo cierto es que en más de una ocasión brota el río

Como una rosa encarnada, es decir, las mieses y el mercurio de la vida.

Ríos que desbordan cualquier mapa como el Amazonas, bayetas 
Eternas que hablan por los hijos del sol sobre el pecho del Urubamba,

Y qué decir del Rímac sórdido y triste y luminoso en las manos de Humareda.

Pero ninguno nos conmueve tanto como el río que bramando baja

Por las calles, halando obreros, campesinos, mineros, maestros,

Mujeres y niños en Marcha hacia el Palacio de Gobierno, que es el morir.

Que es el morir de una clase que aún detenta el poder de matar

Nuestras ilusiones (para qué hablar ya de los overoles mustios,

El horario corrido, el trigo sin cortar, la historia pisoteada).

La Unidad de Servicios Especiales procura en vano contener,

Dispersar aquel río que corre echando chispas a los cuatro vientos:

Llorando, amando, cantando, gritando libertad, despedidos reposición.

Río de gritos que se prenden y se apagan como avisos luminosos. Río 
Incontenible que arrasa charreteras, tanquetas, material deleznable,

Pips, aguas servidas, orden de allanamiento, fuegos fatuos, perdigones.

(Por un recodo de La Victoria, el río acrecienta su metal de torbellino

Insurrecto. Y recordamos que hay ríos apacibles, sencillos como los pueblos

Que brillan en nuestras serranías; mientras con dolor contemplamos

El río de nuestros muertos, nuestros heridos, nuestros presos).

Ríos que nacen en el Parque Universitario, en la Plaza Dos

De Mayo, o no lejos de la María Angola en el Cuzco. Ríos que renacen

Con bravura en alguna calle harapienta de Villa El Salvador. Ríos de manos

Cuarteadas que incendian la noche que agoniza en los arenales de Comas.

Ríos de pan, de no hay vacante, de azúcar, de vuelva usted mañana,

De mi hijo se muere doctor, de pompas de jabón. Ríos 
Profundos, enmielados, transparentes, ensangrentados, libres.

Los viejos maestros dicen que muchas veces un río se quiebra como una

rama seca,

O se abre como una mujer enamorada o se cierra en línea recta como la mira

de un fusil.

Pero lo cierto es que el río de los pobres siempre corre buscando

La Unidad, la tierra fértil, el rumor de la palabra compañero.

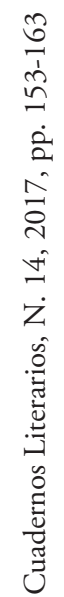

Ser una gota de aquel río planetario es nuestro más caro, humilde deseo.

(En: Casa de las Américas 124, 1981, pp. 120-121) 


\section{PERRO SUELTO}

a G.

Hay poemas que muerden,

Que arañan sin piedad. Bestias

Insaciables que destrozan

Los fundillos, tus mundillos.

Hay otros que ciegan con su resplandor,

Y cierta gracia que le dicen. Fluyen

Sin tropiezo, hasta el nicho

De una antología preciosista.

No faltan los que han sufrido

Algún accidente gramatical

O los que heredaron

La maldición de un padre borracho.

Hay poemas que son un terremoto,

Un tsunami que te arranca el pellejo,

Las vísceras, tus oscuras duplicidades.

Y qué decir de los perros muertos, 
Poemas sueltos

Como este. Perros

Que marchan a la deriva,

Canoas que hacen agua.

Poemas errantes, balas

Perdidas que buscan tus ojos,

Tus abrazos,

Tu perdón. Perros

Querendones como la muerte.

Poemas que labran su resurrección:

Aullidos que se apagan

En algún cuaderno olvidado. 
MUNDO RARO

\section{POEMANGO}

Este poema es de PM, malgré lui.

El mango es pulposo, jugoso, sabroso. Hay

Que comerlo al natural, de preferencia. Así

No perderá su frenesí divino,

ni su amable paisaje.

Dicen que hay mangos aéreos, mangos

Marinos. Todos son bienvenidos:

Vienen de geografías santas y llaneras.

El sol, la lluvia, la tierra

y la mano del labriego 
Hacen este milagro delicioso que alivia

Tu hambre, amengua mi soledad, enmiela tus delirios.

Mis poemas, en cambio, son ácidos, torpes, imperdonables.

No tienen ni glamour ni editor ni aprueban

El casting que demandan el mercado

$$
\text { impío y el fácil manoseo. }
$$

¿Qué resplandor, qué gracia tiene esta escritura?

Pregunta la muchacha seducida

\section{Por un mango marqueteado. Ella}

Prefiere el artificio, el poemango 
MUNDO RARO

De espantos y lunares viejos.

No el poema

Añejo que no sabe ser ni aéreo

Ni marino,

ni nocturno vicio eterno.

(De: Soledades de Solange. Inédito) 